Planas, A.; Soler, P. (2011). Design and application of a system of evaluation indicators for municipal cultural policies, Evaluation Journal, 17, 3, 277-292. ISSN: $1356-3890$

\title{
DESIGN AND APPLICATION OF A SYSTEM OF EVALUATION INDICATORS FOR MUNICIPAL CULTURAL POLICIES
}

Anna Planas Lladó and Pere Soler Masó

University of Girona

Key words: cultural policy, evaluation, indicators, local policy, empowerment

\section{Abstract}

The publication of Agenda 21 for Culture in 2004, gave rise to significant growth in the area of evaluating public cultural policies. Despite these efforts, however, many challenges still remain on the long road to consolidating municipal cultural policies. In order to contribute to the recognition awarded these policies, we propose a system of evaluation indicators aimed at managers and politicians interested in evaluating local cultural policies within the paradigm of empowerment. Based on a research process that begins with a review of the existing literature on evaluation by means of indicators and the most significant proposals for cultural indicators, we design our own proposal for evaluation indicators, which is then validated by a group of experts and applied through a case study. Finally, some reflections are presented regarding the proposal and the importance of evaluating local policies.

\section{CONCEPTION ET APPLICATION D'UN SYSTÈME DES INDICATEURS D'ÉVALUATION DES POLITIQUES CULTURELLES MUNICIPALES}

Key words: politique culturelle, évaluation, indicateurs, politique locale, renforcement des capaticities

\section{French abstract}

La publication de l'Agenda 21 de la culture en 2004, ont donné lieu à une croissance significative dans le domaine de l'évaluation des politiques culturelles publiques. Malgré ces efforts, cependant, de nombreux défis restent encore sur la longue route de consolider une politique culturelle municipale. Afin de contribuer à la reconnaissance accordée à ces politiques, nous proposons un système d'indicateurs d'évaluation destiné aux gestionnaires et les politiciens intéressés à évaluer les politiques culturelles locales sur le paradigme du empowerment. Basé sur un processus de recherche qui commence par une revue de la littérature existante sur l'évaluation au moyen d'indicateurs et les propositions les plus significatives pour les indicateurs culturels, nous concevons notre propre proposition d'indicateurs d'évaluation, qui est ensuite validé par un groupe d'experts et appliquées par le biais une étude de cas. Enfin, quelques réflexions sont présentées au sujet de la proposition et l'importance d'évaluer les politiques locales. 


\section{DESIGN AND APPLICATION OF A SYSTEM OF EVALUATION INDICATORS FOR MUNICIPAL CULTURAL POLICIES}

In order to evaluate public policies it is necessary to have a good working knowledge of existing models and paradigms and use these as a starting point. Said public policy models are based on a theory of social change (Meny and Thoening, 1992). In order to observe these policies and deduce their individual purpose, we may analyse their aims, the subjects affected, the executors trusted with application of the relevant governmental measures, etc. In the specific case of cultural policies, we can find certain common links between these political trends, particularly in the continued presence of cultural policies over different historical periods ${ }^{1}$, although we do observe a certain diversity in the names given to the models.

Although the predecessor of these models is State or private patronage, based on the direct link between creators and the authorities, the first cultural policy model is the Democratisation of Culture or Enlightenment. This model is committed to education and culture as elements for developing democracy. It has as its principal objective making cultural assets (culture as art and heritage) available to the population as a whole by means of mechanisms of cultural diffusion. What characterises the second model, Cultural Democracy or Empowerment, is a commitment to a citizenry active in cultural creation. The latter model, called Social, economic and cultural efficiency, Cultural elements on offer and their management, Economic Impact and Entertainment presents culture as a clearly instrumental and pragmatic element. It denotes the strategic importance of culture fundamentally in the economic, and to a lesser extent the political and social, domains. It is, then, about emphasising the profitability and efficiency of culture in the light of social and territorial needs. With regard to the Economic Impact model, Eurocult 21, it addresses a different direction it calls Entertainment, linked to capitalising the market and people's need for fun. This trend prioritises entertainment over enlightenment in different cultural facilities and programmes to respond to the expectations of an audience continuously looking for and more instantaneous experiences, stellar acts, shows and entertainment.

We must consider these models as tools for analysis rather than true operational models of cultural policies. All authors agree on the fact that nowadays there are numerous programmes and initiatives in existence that correspond to the different models and that boundaries are not always clear, meaning we can find many areas of overlap.

The purpose of this article is to present a proposal for a system of evaluation indicators aimed at managers and politicians interested in evaluating local cultural policies from a viewpoint related to the paradigm of empowerment and points of convergence with other models (for example, enlightenment). We have applied, then, an ideological model which focuses on enabling citizens and giving autonomy to groups and communities, which encourages policies giving access to culture, and which stimulates lifelong creative and educational processes. We therefore propose the promotion of instruments that help policies turn citizens into protagonists rather than spectators, creators rather than consumers, facilitators rather than receptors. In other words, policies for constructive and enriching leisure time that generate participative dynamics and involve citizens, and which might counterbalance the strong current development of entertainment or economic impact policies. Given the above, what are required are evaluation processes that involve the citizens themselves (in particular participative evaluation processes). We believe that a proposal for a system of evaluation indicators which is aimed at cultural policies, despite being based on the empowerment paradigm, may serve as an optimum 
complementary measure by contributing rigour, a systematic approach and raised awareness to a host of different processes and decisions.

The first two sections of the article focus on reviewing how cultural policies are evaluated using indicators. The following section presents the main challenges currently facing this type of policy. Section four presents the evaluation aims we propose, followed by the methodological process and the final indicator proposal. In the final section we present some conclusions regarding the indicator proposal and the importance of evaluating policies on a local level.

\section{The evaluation of municipal cultural policies: an international overview}

The first appearance of social indicators dates back to the use of statistical indicators for improving public health and social conditions by social reformers in Belgium, France, the UK and the US from 1830 onwards. It was not until the beginning of the 20th century, however, that the collection of indicators and statistical data would be explicitly linked to political debate, although this has always been one of the points of conflict in the history of indicators, as highlighted by Cobb and Rixford (1998). In 1910, the Russell Sage Foundation in the US began development of what have come to be known as community indicators, using similar processes to those which have been newly employed since 1990. The Sixties witnessed the appearance of a deductive and analytical approach in the field of social indicators, the result of successful management of the political economy. In 1966, Bauer saw that the application of indicators to the social system would represent a reliable basis on which to establish priorities for programmes, help to establish clear objectives and policies, and simplify the task of evaluation (Kingsley, 1999). What would ultimately give a boost to the social indicator movement was the publication of Social Indicators in 1966. Its authors proposed the development of a system of social indicators for guiding political decision-making. At the same time, this new trend had its opposers, such as Sheldon, who believed that social indicators could not follow the same steps as the economic model, social objectives being more ambiguous, social problems less clear than economic ones, and theoretical economic bases clearer than those used in social analyses.

The Seventies and Eighties witnessed an abundance of studies and descriptive approaches based on indicators in the social field. Numerous international organisations and countries compiled annual statistics reports focusing on social conditions. In the United States, however, interest in indicators was on the wane, particularly from the Eighties onwards. According to Kinsgley (1999) and Cobb and Rixford (1998) this lack of interest could be attributed to the expectations that had been projected onto the indicators systems, the cost of data collection, the limited practical use of indicators in political practice, the lack of a social theoretical framework comparable with the economic model, and the lack of a standardised measuring tool in the social field comparable with the use of currency in economics. Despite this, the social indicators movement inspired the development of environmental indicators, providing a new framework for the use of indicators at the beginning of the Nineties.

Cultural indicators have been only a more recent development, probably due to the fact that cultural policy was not of interest to governments until well into the second half of the 20th century $^{2}$, but also because of the methodological difficulties still to be overcome (Carrasco, 1999) and the failure to define the term "culture". This lack of a definition was a cause for concern and controversy for different congresses, meetings and projects throughout the Seventies and Eighties, along with the lack of a single theoretical model, an added difficulty 
when it came to producing a system of indicators, and the difficulty in defining the areas of culture and its productive heterogeneity (Bonet, 2004).

One of the first reports of reference on cultural indicators was the first World Culture Report compiled by UNESCO in 1998. The report provided evidence of a lack of basic cultural indicators for UNESCO Member States, particularly in the poorer countries. It is only after the mid-Nineties that studies and research began on local cultural indicators.

From the end of the Nineties onwards, the US and Canada incorporated cultural indicators into their community indicators systems, which were based on models for quality of life, sustainability and community health ${ }^{3}$. It was also from the second half of the Nineties onwards and during the first half of the following decade that there began to appear projects on local indicators focusing exclusively on cultural indicators, as is the case with Silicon Valley (Walesh $\&$ Henton, 2001). This can be considered a reference work for community culture indicators in the US and Canada. Also in the US, we find Arts and Culture Indicators in Community Building Project, (Kingsley, 1999) by the Urban Institute and the National Neighborhood Indicators Partnership, a project aimed at proposing indicators for the cultural development of communities and contributing tools for creating policies, local planning and constructing communities. In line with this, it is also interesting to highlight the work carried out in Canada in 2007 by Creative City Network's, Center of Expertise on Culture and Communities in collaboration with Simon Frases University. The study (Duxbury, 2007) identified methodological frameworks and guidelines for developing cultural indicators on a local level.

We would also like to highlight the contribution of the Australian Hawkes (2001), and his publication The fourth pillar of sustainability. Culture's essential role in public planning, which serves as an important reference in perceiving culture as a dimension of human development that must be taken into account in all public action. Hawkes himself proposes an interesting array of indicators.

From the mid-Nineties until the middle of the following decade we can also point to different studies carried out in the UK which received the backing of the British government's Department for Culture, Media and Sport (DCMS) and Arts Council England. Of these, we may highlight, for example, Arts Council England's Local Performance Indicators for the Arts (2003), or Museums, Libraries and Archives Council of London (2005). We would particularly like to highlight the work done by Comedia in producing proposals for cultural indicators and studies on the social impact of arts and culture. Among these we find Matarasso's proposal for cultural indicators (1999), the study conducted by Landry, Greene, Matarasso and Bianchini (1996) on the importance of cultural activity in the urban renovation process, and Landry and Bainchini's study Creative City (1994), in which they propose indicators to be used as a creativity index for improving the health of cities in economic, social, environmental and cultural terms. In the British literature on indicators we can also find some studies and research work on towns or regions that make use of cultural indicators for local development ${ }^{4}$.

Among the local cultural indicator studies conducted in other countries, it is also worth mentioning Eurocult 21 (Urban Cultural profile Exchange Project in the 21st Century) (Robinson, 2005), which, based on the premises of Agenda 21 for Culture, examines the role of cultural policy in 12 European cities and provides future recommendations. The document establishes a comparative conceptual framework for analysing and facilitating research into urban cultural policies that make culture the focus of their governance. It also suggests ideas for developing a system of municipal indicators to further the implementation of Agenda 21 for 
Culture. In addition to the above, Ciudades y Gobiernos Locales Unidos - Grup de Treball en Cultura (2006) is currently carrying out the project Indicadores culturales y Agenda 21 de la cultura, which has an interesting framework for interpreting local cultural policies.

\section{The evaluation of municipal cultural policies in Spain}

In Spain the inflection point arrived in 2004 with the approval of Agenda 21 for Culture, although some precedents do exist. One such case is that of Carrasco (1999), who conducted a factorial analysis of sociocultural indicators in the Valencian Community. This research is interesting from a quantitative viewpoint due to the type of indicators it employs and its analysis of each municipality studied. It basically focuses on factors regarding the consumption and diffusion of culture, but has little impact on qualitative elements. A second contribution worth mentioning is the work carried out by the Spanish Federation of Municipalities and Provinces (2007) which, with the co-operation of the Ministry for Culture and within the framework of Agenda 21 for Culture, proposed a self-evaluation system with regard to local cultural policies. The proposal contemplated quantitative and qualitative indicators that can be fully or partially used by different municipalities for understanding and improving their actions and cultural policies.

\section{Current challenges in the evaluation of municipal cultural policies by means of indicators}

An analysis of the above proposals reveals that there are still some weaknesses in the existing evaluation of municipal cultural policies. Cultural indicators systems may address aspects of culture, but they go into very little depth when it comes to the more educational and social aspects of the same. Most of them focus on aspects relating to the diffusion of culture, such as those designed by Carrasco or Eurocult 21 (Robinson, 2005). The availability of data and the decision to use comparative methods have helped to produce quantitative indicators that do not always allow for the perception of fine distinctions in local policies. It is essential to do more work in this area and incorporate qualitative evaluation as a complementary and alternative dimension within cultural analysis. Municipal public policies are conditioned by reference frameworks which relate to the relative authority of the autonomous region and/or the state. Therefore, international proposals cannot always be adapted to the possibilities and characteristics of Spanish municipalities' sphere of authority. As a final consideration, most of the existing proposals focus on large municipalities and cities. These proposals are not always appropriate for the needs and characteristics of small and medium-sized municipalities, which suffer from a lack of instruments adapted to their size and particular needs.

As highlighted by the International Federation of Arts Councils and Culture Agencies (IFACCA) (2005), there are still challenges to be met with regard to cultural policy indicators:

- There is no broad consensus on cultural indicators.

- It would appear to be difficult to draw generalised conclusions on the basis of case studies due to the difficulty of comparison.

- There is a certain mistrust with regard to the quality of current cultural indicators and cultural statistics, and in particular their suitability for programmes and policies. The most common problems with regard to analysing these indicators are: confusion surrounding what indicators actually are and how they are to be used, a lack of qualitative data, frameworks which are difficult to manage, the aims of policies are imprecise (the imprecision of cultural policies makes it difficult to develop indicators for clear policies). 
- There is little contact between the researchers and institutions that produce indicators. We therefore find work being duplicated and differing focuses. Although each country has different cultural priorities, common or generic aspects do exist that could be worked on more quickly if there were more coordination.

All in all, the incorporation of cultural indicators or groups of cultural indicators in different studies and projects and the speeding up of this process since the approval of Agenda 21 for Culture may gradually help to establish reasons for including culture in public policies. They may also contribute to facilitating empirical data and consequently lead to the consolidation of the theoretical framework in this area, which, although developed, is extremely difficult to apply (IFACCA, 2005).

With the aim of contributing further tools for evaluating municipal cultural policies, below we present the process for constructing a proposal for evaluation indicators which is framed within cultural empowerment policies in terms of evaluation objectives and content. That is, the criteria and aims for evaluating these policies were obtained from a position of empowerment within this paradigm, which has led to special attention being paid to the social and community aspects of cultural policy promoted by the municipal government.

The evaluation of cultural policies requires concrete contributions that provide a systematic approach and help raise awareness in this area. Even when viewing cultural politics from the paradigm of empowerment, a proposal to evaluate by means of quantitative and qualitative indicators may prove very useful in systematising data collection and as a guide to local cultural policies for both politicians and municipal managers. Our proposal therefore falls within a concrete framework, with well-designed aims and a detailed design using quantitative and qualitative indicators. Special care has been taken to propose a model suited to the needs and characteristics of small and medium-sized towns, for which the existing proposals are not always appropriate, often being intended for and implemented by large institutions or municipal areas.

The system of evaluation indicators presented here is intended as an open instrument adaptable to any changes that may be caused by its application to diverse contexts. It has been successfully applied in one town to date. We are convinced that as it is applied in other towns its structure will be improved, and with this its effectiveness.

\section{An outline summary of the objectives of cultural empowerment policies}

A system of indicators would have no validity without a conceptual context to give it meaning and points of reference by which to evaluate it. We have taken as our starting point the models and paradigms of cultural policies, and more precisely the paradigm of empowerment. What we have applied, then, is an ideological model that focuses on enabling citizens and giving autonomy to groups and communities, encourages policies that provide access to culture, and stimulates lifelong creative and educational processes.

This position provides us with a starting point to guide and evaluate the cultural actions to be taken in municipalities. Framed within this paradigm, the cultural policies we shall study encompass any services, programmes, projects or activities included within various different policy areas which have as a common objective the fostering and development of the most social dimension of culture, i.e. all those which operate in the fields of participation, social 
inclusion and the creation of identity, and in the processes of formation, dynamization, creation and promotion of the culture of each community. Within this framework and working on the basis of bibliographical research ${ }^{5}$, we set ourselves seven specific objectives to cover the full range of activities and aspects that should be included in any municipal cultural empowerment policy, and which we outline in Table 1, together with the most important contents and aspects that should be included in each of the evaluation objectives proposed.

\title{
Table 1: Evaluation objectives for and basic contents of cultural empowerment policies adopted by municipal councils
}

\begin{abstract}
1. To analyse the scope and characteristics of the facilities and interaction between the municipal services available.

Facilities and infrastructures are essential tools for community development in that they are communal spaces which permit both the provision of the cultural activities on offer in an area and the subsequent contact and interaction with them. It is important to take into account: the diversity of the existing facilities or services; the means available for providing activities in terms of both technical aspects and infrastructures; the presence of specialized technical and professional staff; and the degree of coordination between services.
\end{abstract}

2. To examine the cultural activities on offer and the resources that enable local entities to foster and promote these activities.

Cultural activities contribute both to personal and community development and to the creation of a sense of identity through the participation and independent management of the groups involved. Cultural policies need to take into account: diversity in terms of both those organizing activities and of the variety and different ways of organizing the cultural activities concerned, the financial resources available, the quality of the activities on offer, and the coordination and networking required to make the efforts involved coherent and profitable.

3. To analyse the assistance provided and policies that give access to the municipal cultural activities on offer.

Cultural policies should not be exclusive, but rather must cater to and provide opportunities for the full range of local residents' cultural requirements and interests. In order to ensure this, councils may employ strategies such as the following: diversifying the activities on offer; promoting initiatives involving local social networks; introducing cost-reduction policies benefiting a wide range of groups decentralizing and ensuring fair distribution of facilities; monitoring local residents' opinions with regard to their requirements and interests.

4. To identify whether programmes are proposed from a subjective viewpoint and not simply in terms of the objective requirements of the cultural sector concerned.

Transversal contacts and networking can encourage the proposal of programmes, projects and activities from a more universal viewpoint that is more enriching for local citizens. Councils may foster transversal contacts and networking in the following ways: by encouraging political and specialist leadership; by fostering systematic and methodical approaches; by employing clear evaluative procedures; and by taking into consideration the cultural and/or educational aspect.

5. To analyse the support given to local creative talent and the municipal backing provided to foster local citizens' creativity.

Creative expression contributes to innovation, to social and cultural change, and also to the forging of a community spirit. The following approaches are therefore required: encouraging local creative talent; offering aid for creative activity; making creative forms of expression accessible to local citizens; and taking innovation into account as a criterion for assistance in cultural projects.

6. To examine municipal support for the diversity of cultures and origins present in the municipal area in terms of the use, creation and expression of cultural activities.

In a multi-cultural society, development and change in any municipal unit are dependent on a willingness to listen and to engage in dialogue between the various cultural groups living in the area. With this in mind, cultural policies will be subject to: fostering programmes of educational adaptation and cultural promotion; diversifying the cultural activities on offer; developing multi-cultural programmes; encouraging citizens' initiatives originating from collectives representing cultural minorities; and introducing access programmes for groups threatened by poverty or social exclusion.

7. To analyse municipal support in promoting the creation of associations and citizen participation.

Participation is an indispensable prerequisite of the capacity for autonomous organization and individual and collective involvement in community projects. Cultural policies should encourage it in: by fostering the creation of associations; by providing resources to citizens to promote their 
participation; and by encouraging processes of institutional participation.

\section{Towards the construction of a system of evaluation indicators}

Our definition of the conceptual framework proposed in the preceding section constituted the first phase in constructing a system of indicators for evaluating the cultural policies adopted by municipal councils. This defined the objective of our study and the theoretical and political context in which our system of indicators is to be positioned. Once this framework had been established, we conducted our research in 3 phases: the initial proposal of indicators and the design of instruments for their construction and implementation; expert validation of the proposal of indicators and their empirical application; and by way of conclusion, the final drafting of the proposal. Let us now examine these phases at greater length.

Adopting a more detailed approach after defining the political and theoretical context, parameters were established for defining how each objective would be evaluated. This led us to establish the relevant indicators and design instruments so as to define and construct each indicator. These instruments enable us not only to define the criteria for reading and interpreting each indicator, but also understanding and interpreting each indicator within the system proposed. Two types of instrument were designed for construction of the indicators: one to provide a quantitative estimate, and the other to deal with more qualitative aspects.

In relation to the quantitative estimate, we designed 15 fields to define the aspects that were most relevant for the application, understanding and interpretation of each indicator: denomination, reference, specific objective, precise objective, formula, technical information, structure, unit, regularity, source of information, level, interpretation and limitations.

With regard to the qualitative analysis, we defined the parameters of analysis for each evaluation objective. These parameters are as follows: framework for the objective, indicators and level of success, score, and additional information. Various indicators are presented to evaluate the objective, each of which is broken down into 4 levels in accordance with its success in meeting the criteria (based on the model proposed by Arts Council England, 2003). The 4 levels are:

- Advanced: The desired situation has been attained with regard to the indicator or objective that we proposed.

- Established: Action is being taken to attain the situation of the indicator and/or objective. Some aspects corresponding to the indicator and/or objective have been consolidated.

- Emerging: Certain elements corresponding to the indicator and/or objective have begun to be attained, but the process is only in its initial stages.

- Absent: The indicator or objective has not been attained.

\section{Validation of the indicator proposal}

Once the tools for constructing the indicators have been designed and the first proposal has been defined, we enter the third phase of the research process: that of validation. Validation is conducted on the basis of two methodologies: validation by experts; and the application of the proposal to a case study.

Expert validation is intended to lend the proposal validity and reliability, as happens with triangulation systems for researchers, whereby reliable and valid data can be obtained for 
research through the use of two or more independent observers or participants (Cohen \& Manion, 2002). Our expert validation was carried out in two stages. The first, considered a pilot test, was vital in designing the validation instrument. It had a dual objective: on the one hand, to check understanding of the material prepared for validation; and on the other, the actual validation of the indicators presented. There were 5 validators, all experts and/or professionals connected to the field of cultural activities and evaluation. Their contributions were used to prepare the material and fine-tune the indicators that were to be sent in the second stage. This second stage involved 14 validators from different parts of Spain, and in the case of 4 of these we conducted prior interviews. Of the 14 referred to, $50 \%$ were academics linked to the study of cultural subjects, followed by $28.6 \%$ who were academics linked to the field of public policy. The others were academics from the field of evaluation and professionals working in the cultural domain.

The validation process led to the conceptual clarification of certain indicators and the limitations that should be applied to some of them, especially with regard to data collection. The need was also noted to simplify and break down some qualitative indicators to facilitate a better application of the instrument concerned, and eliminate some quantitative indicators. The process also made it possible to evaluate the importance and significance of each indicator in relation to the attainment of its objective (which, in turn, made it possible to differentiate between basic and secondary indicators).

The changes proposed by the expert validation process were included in a new proposal which was subjected to empirical testing through its application in a particular municipal area. The methodological process employed was that of the case study. Within the diversity of types of case study ${ }^{6}$, and bearing in mind the classification made by Stake (1998), this point in the process constitutes an instrumental case study. Its objective was to attain general understanding of a subject or of a theoretical aspect on the basis of a deliberately selected specific case. The aim of our case study was to confirm, change or increase our knowledge of the evaluation of municipal councils' cultural policies and to carry out an exploratory analysis for its application in other municipal areas. The municipal area selected for the case study was a village of alomst 4,000 inhabitants located in Spain. Its high level of social and cultural dynamism and its large number of cultural services in proportion to its demographic characteristics, together with the ease of access to relevant data for researchers, were key elements for this choice?

\section{The final indicator proposal for evaluating municipal cultural policies}

The final indicator proposal for evaluating local cultural policies comprises a total of 58 indicators (Table 2), organized around 7 evaluation objectives. The proposal includes basic and secondary indicators, and also distinguishes between quantitative and qualitative indicators. Basic indicators are those considered necessary for evaluating the objective to which they refer. For their part, secondary indicators (italic) make it possible to conduct a more detailed evaluation of the objective and to contribute additional information which may be of interest for the analysis of cultural policies ${ }^{8}$.

Table 2: List of quantitative and qualitative indicators

\begin{tabular}{|c|c|}
\hline QUANTITATIVE INDICATORS & QUALITATIVE INDICATORS \\
\hline \multicolumn{2}{|c|}{$\begin{array}{l}\text { OBJECTIVE } 1 \text {. To analyse what municipal and socio-cultural facilities and services are available, their characteristics and the } \\
\text { relationship established between them }\end{array}$} \\
\hline $\begin{array}{l}\text { Surface area of public spaces reserved for } \\
\text { cultural activities per } 1000 \text { inhabitants. }\end{array}$ & $\begin{array}{ll}\text { 1.A } & \text { Qualified staff at the facilities } \\
\text { 1.B } & \text { Stability of employment of facility staff }\end{array}$ \\
\hline $\begin{array}{l}\text { Availability of places for study and/or reading } \\
\text { in municipal libraries or reading rooms per } \\
1000 \text { inhabitants }\end{array}$ & $\begin{array}{l}\text { Number of facilities available with respect to socio- } \\
\text { cultural needs }\end{array}$ \\
\hline
\end{tabular}




\begin{tabular}{|c|c|c|c|}
\hline 1.3 & $\begin{array}{l}\text { Availability of public performance spaces per } \\
1000 \text { inhabitants }\end{array}$ & $\begin{array}{l}\text { 1.D } \\
\text { 1.E } \\
\text { 1.F } \\
\text { 1. } . \mathrm{H}\end{array}$ & $\begin{array}{l}\text { Planning of socio-cultural services and facilities } \\
\text { Technical resources available for doing activities at } \\
\text { the socio-cultural facilities and services } \\
\text { Evaluation of municipal socio-cultural services and } \\
\text { facilities } \\
\text { Coordination between officers in charge of socio- } \\
\text { cultural services and facilities } \\
\text { Undertaking of joint socio-cultural projects between } \\
\text { municipal services and facilities }\end{array}$ \\
\hline \multicolumn{4}{|c|}{$\begin{array}{l}\text { OBJECTIVE } 2 \text {. To study the municipal socio-cultural activities on offer or those receiving municipal support and the resources } \\
\text { of local bodies invested in the organisation and promotion of said activities }\end{array}$} \\
\hline 2.1 & $\begin{array}{l}\text { Annual cultural activities programmed directly } \\
\text { by the municipal government per } 1000 \\
\text { inhabitants. } \\
\text { Amount of annual municipal budget allocated } \\
\text { to direct programming of socio-cultural } \\
\text { activities by local government }\end{array}$ & 2.A & $\begin{array}{l}\text { Coordination of professionals and agents involved in } \\
\text { designing and organising socio-cultural activities. } \\
\text { Planning documents written regarding activities } \\
\text { organised directly by the local body } \\
\text { Evaluation of the socio-cultural activities on offer } \\
\text { organised directly by the town council }\end{array}$ \\
\hline 2.3 & $\begin{array}{l}\text { Annual cultural activities on offer receiving } \\
\text { municipal government support but organised } \\
\text { by third parties per } 1000 \text { inhabitants. }\end{array}$ & 2.D & $\begin{array}{l}\text { Planning of activities receiving municipal support } \\
\text { and organised by third parties }\end{array}$ \\
\hline 2.4 & $\begin{array}{l}\text { Amount of annual municipal budget allocated } \\
\text { to support for socio-cultural activities by local } \\
\text { government }\end{array}$ & $\begin{array}{l}2 . \mathrm{E} \\
2 . F\end{array}$ & $\begin{array}{l}\text { Range of socio-cultural activities on offer } \\
\text { Evaluation of documents written regarding activities } \\
\text { organised directly by the local body }\end{array}$ \\
\hline 2.5 & $\begin{array}{l}\text { Percentage of annual days municipal socio- } \\
\text { cultural spaces and facilities are open }\end{array}$ & $2 . G$ & $\begin{array}{l}\text { Evaluation of activities receiving municipal support } \\
\text { and organised by third parties }\end{array}$ \\
\hline 2.6 & $\begin{array}{l}\text { Amount of annual municipal budget allocated } \\
\text { to advertising socio-cultural activities }\end{array}$ & 2. $H$ & $\begin{array}{l}\text { Advertising and diffusion of socio-cultural activities } \\
\text { on offer }\end{array}$ \\
\hline 2.7 & $\begin{array}{l}\text { Number of joint projects between two or more } \\
\text { facilities in one year in comparison with the } \\
\text { total number of socio-cultural projects }\end{array}$ & & \\
\hline \multicolumn{4}{|c|}{$\begin{array}{l}\text { OBJECTIVE 3. To analyse attendance at and access policies for municipal socio-cultural activities or those receiving municipal } \\
\text { support }\end{array}$} \\
\hline 3.1 & $\begin{array}{l}\text { Annual attendance for socio-cultural activities } \\
\text { per } 1000 \text { inhabitants }\end{array}$ & & $\begin{array}{l}\text { Policy for access to municipal socio-cultural } \\
\text { activities on offer }\end{array}$ \\
\hline 3.2 & $\begin{array}{l}\text { Annual users of municipal libraries or reading } \\
\text { rooms per } 1000 \text { inhabitants }\end{array}$ & 3.B & $\begin{array}{l}\text { Consulting citizens with regard to socio-cultural } \\
\text { needs and demands }\end{array}$ \\
\hline \multicolumn{4}{|c|}{$\begin{array}{l}\text { OBJECTIVE } 4 \text {. To detect whether municipal resources are designed and invested in programmes that work from the perspective } \\
\text { of the subject and not only from the object or sector }\end{array}$} \\
\hline 4.1 & $\begin{array}{l}\text { Number of transversal plans and programmes } \\
\text { provided for in current legislature by the local } \\
\text { government } \\
\text { Number of projects and activities undertaken } \\
\text { with the involvement of } 2 \text { or more local } \\
\text { government departments in comparison with } \\
\text { the total number of socio-cultural projects and } \\
\text { activities }\end{array}$ & $\begin{array}{l}\text { 4.A } \\
\text { 4.B } \\
\text { 4.C } \\
\text { 4.D } \\
\text { 4.E } \\
\text { 4.F }\end{array}$ & $\begin{array}{l}\text { Transversality in the political programme of the } \\
\text { government team } \\
\text { Promotion of transversal plans and functional and } \\
\text { political organisational charts } \\
\text { Methodology used for networking } \\
\text { Culture and/or education in transversal plans } \\
\text { Leadership of transversal plans } \\
\text { Regular review and adaptation of transversal plans } \\
\text { and programmes }\end{array}$ \\
\hline OBJ & VE 5. To analyse the support awarded to local cre & $\begin{array}{l}\text { s and } \\
5 . \mathrm{A} \\
5 . \mathrm{B} \\
5 . \mathrm{C}\end{array}$ & $\begin{array}{l}\text { icipal commitment to promoting citizen creativity } \\
\text { in local creativity and identity } \\
\text { Create innovation in heritage and historical records } \\
\text { Resources for promoting creativity }\end{array}$ \\
\hline \multicolumn{4}{|c|}{$\begin{array}{l}\text { OBJECTIVE } 6 \text {. To study municipal commitment to the diversity of the municipality in terms of its culture and citizens in the use } \\
\text { creation and expression of socio-cultural activities }\end{array}$} \\
\hline 6.1 & $\begin{array}{l}\text { Number of municipal annual socio-cultural } \\
\text { activities aimed at different ages } \\
\text { Number of municipal annual socio-cultural } \\
\text { activities receiving the support of local } \\
\text { government and organised by minority cultural } \\
\text { groups } \\
\text { Number of municipal cultural activities aimed } \\
\text { at cultural minorities }\end{array}$ & $\begin{array}{l}6 . B \\
6 . C\end{array}$ & $\begin{array}{l}\text { Accessibility to the socio-cultural activities on offer } \\
\text { and support in the creation and expression of groups } \\
\text { or collectives at risk of poverty } \\
\text { Intercultural environments and programmes } \\
\text { The inclusion of the disabled }\end{array}$ \\
\hline \multicolumn{4}{|c|}{ OBJECTIVE 7. To analyse municipal support existing for the promotion of associations and citizen participation } \\
\hline 7.1 & $\begin{array}{l}\text { Percentage and type of associations per } 1000 \\
\text { inhabitants } \\
\text { Population members of municipal associations } \\
\text { per } 1000 \text { inhabitants }\end{array}$ & 7.A & $\begin{array}{l}\text { The political programme promotes citizen } \\
\text { participation on an institutional, community and } \\
\text { individual level } \\
\text { Promotion of community participation }\end{array}$ \\
\hline 7.3 & $\begin{array}{l}\text { Percentage of associations that have carried } \\
\text { out socio-cultural activities with municipal } \\
\text { support in one year in comparison with the } \\
\text { total number of associations } \\
\text { Percentage of annual socio-cultural activities } \\
\text { on offer carried out by associations with } \\
\text { municipal support }\end{array}$ & $\begin{array}{l}\text { 7.C } \\
\text { 7.D } \\
\text { 7.E }\end{array}$ & $\begin{array}{l}\text { Institutional participation } \\
\text { Individual participation } \\
\text { Coordination between associations and support } \\
\text { from municipal manager }\end{array}$ \\
\hline
\end{tabular}




\begin{tabular}{|ll|l|}
\hline 7.5 & $\begin{array}{l}\text { Informal socio-cultural groups that have } \\
\text { carried out socio-cultural activities in one year } \\
\text { with municipal support per } 1000 \text { inhabitants } \\
\text { Annual number of days that spaces run and } \\
\text { owned by the municipality are used by citizens } \\
\text { for socio-cultural activities. }\end{array}$ & \\
\hline
\end{tabular}

The result, then, is a proposal which is both selective and open. It can be enlarged or modified with a range of different indicators, and applied either fully or partially, so that objectives can be evaluated separately. Therefore, a municipal council may apply only the indicators of those objectives which it is interested in evaluating, although full application is recommended in view of the relational character that links the various different indicators together.

The instrument is intended for use by municipal managers and politicians, since it is they who promote and/or implement municipal policies, have an in-depth knowledge of the municipal area and have all the necessary information at their fingertips. Although the responsibility for its application is assumed by managers and/or politicians, the implementation process may be undertaken in a variety of ways and may involve differing levels of participation on the part of the public, such as, for example, its application on the basis of more or less informal mechanisms for participation by local citizens.

\section{Conclusions}

There is a significant heterogeneity in the evaluation of cultural policies by means of indicators, both in terms of theoretical reference frameworks, and objectives and criteria for data collection. There is little systemisation in data collection and a lack of evaluation instruments, which makes it difficult to apply existing indicators systems. This heterogeneity leads to dispersion, difficulties in making comparisons, the duplication of efforts, and little rigour.

In view of the experiences analysed here, we would also like to point out the added difficulty in finding evaluation instruments adapted to the realities and needs of small and medium-sized municipalities. Although the objectives we formulate for cultural policies may be the same in both small and large municipalities, the organisation of these policies will probably differ according to the size of the municipality. The tendency for small and medium-sized municipalities is to organise themselves into departments that draw together policies from different sectors: culture, education, youth, sport, festivals, etc. These departments tend to have a single politician overseeing them and, at best, another non-specialised manager with general duties for implementing policies. It is therefore clear that the resources, organisation and fundamental reality of smaller town councils differ from those of larger town councils, which have more differentiated areas, specialised personnel and a diversity of policies, and that this must require at least minimally different methodologies, intervention strategies and evaluation systems. Research, designing instruments, redefining methodologies, creating new paradigms, innovation, etc., have all traditionally been promoted in urban environments, either because they have more resources for training and research, or there is a higher concentration of managers, thereby multiplying the possibilities of reflecting on action.

The system of evaluation indicators we propose adds rigour to the implementing of local cultural policies, which are very often intangible and difficult to visualise. It may also prove a valuable learning tool for raising awareness of a town's reality and needs and the type of actions we promote in the area of cutural policy. This is learning aimed at transforming and improving current practices. 
With regard to application of the instrument, we consider it a tool to be applied regularly and over the long term, which in some cases may include processes for citizen participation (evaluation of qualitative items, interpretation of quantitative data, etc.). It is not an instrument to be used merely to take a snapshot of a place at a specific point in time. If we consider that all public actions provoke an alteration in the status quo with regard to social aspects, we must remain very aware of the evolution and contextual changes occurring with the application of policies. As with any system of indicators, we recommend it be applied alongside other evaluation methodologies, which in our view would have to be more participative in nature, such as action research or participative evaluation processes. Bearing in mind that the theoretical background on which our proposal is based is that of empowerment, and therefore, a commitment to an active citizenry. It is important to apply this indicators system alongside methodologies that incorporate the citizen as an active agent in the process of evaluating public policies, helping to adapt these policies to local realities. We are convinced that these evaluative models and strategies can complement one another and contribute more rigour, credibility and solidity to the domain of cultural policies.

Among its limitations, we would like to mention that the evaluation system by means of indicators is aimed at political action by public administration and does not therefore evaluate the entire cultural dynamics of the municipality. If this is what is required, other aspects should be taken into account, such as the community culture promoted within other sectors (private, tertiary sector, informal networks), or other areas of culture such as heritage, cultural industries, as well as the cultural preferences of different cultural groups, for example. The instrument is not intended to cover all aspects relating to culture, and is therefore limited in this respect.

Finally, we would like to highlight the importance of evaluating public policies by different sectors, including within this cultural policies. Policy evaluation is justified by the pressure on administrations to determine the extent to which public intervention produces an improvement in individual or social well-being, how this is produced and how it could be achieved more effectively (Ballart, 1996). In short, to stimulate reflection on action and learning in order to adapt public policies to social needs. If we focus on cultural policies, we must take it into account that these are instrumental policies, not ends in themselves, contributing to the development of other sectors (economic, health, education, etc.). They are policies that contribute to improving quality of life, affirming cultural identity and developing a local culture (De la Durantaye, 2002). In this respect, their evaluation is fundamental if we are to capture and visualise the effect of these policies on the development of the territory. It is essential, however, and particularly in Spain, to improve the evaluation system. It will be necessary to make an impact on those aspects which have led to evaluation systems not being more developed in Spain, such as the lack of tradition in the field of applied social research, the lack of incentives in evaluation systems, the strong bias in favour of certain parties (Viñas, 2009). It will also be important to abandon the prevailing culture of evaluation being used as a sanction, and its manipulation to justify or endorse actions that have already been undertaken, or to eliminate programmes in a premeditated way, among other things. It will therefore be necessary to enter into evaluative dynamics that allow us to use evaluation as a learning tool for improvement and transformation and to bring rigour to the sector.

\footnotetext{
${ }^{1}$ In this section we shall not be providing an exhaustive account of the historical evolution of these models or paradigms. For a more in-depth historical overview of cultural policies, consult the following: Bianchini (1993), Bouzada (1993), Bouzada (2004), Caride and Meida (2000), Robinson (2005), López de Aguileta (2000), Matarasso \& Landry (1999) and Zallo (1995).
} 


\footnotetext{
${ }^{2}$ Bonet (2004) attributes this in part to the low level of cultural activity as a sector of economic activity.

${ }^{3}$ In this respect, Duxbury (2003: 1) notes that "Three frameworks are currently used to conceptually frame cultural indicators development: sustainability, quality of life, and societal communications. At the local level, community sustainability and quality of life resonated most. These fields have developed a range of methodological frameworks (including process guidelines, indicator selection/development criteria, and critical issues), which are valuable to informing cultural indicator development"

${ }^{4}$ For further information on cultural policies in the United Kingdom and work on indicators, see the study by Poirier (2003).

${ }^{5}$ See (among others) López de Aguileta (2000), Pose (2006).

${ }^{6}$ See Rodríguez, G.; Gil, J; García, E. (1996: 92-98), Stake, R.E (1998: 16-17), Vázquez, R.; Angulo, F. (2003:1617), Bisquerra, R. (coord.) (2004: 314-316).

7 For Stake (1998), the first criterion for the selection of a case must be the highest possible degree of exploitability of what we learn, and in instrumental studies, using an unusual case can be illustrative of what goes unnoticed in typical cases.

${ }^{8}$ See Planas (2009) for the developement of indicators
}

\section{Bibliographical references}

Arts Council England (2003) Handbook of local performance indicators for the arts. Arts Council England. Available at: http://www.lga.gov.uk/download.asp?path=/Documents/Agenda/cultural/170303/item6.pdf. (site visited: 20 december 2007)

Ballart, X. (1996) 'Modelos teóricos para la práctica de la evaluación de programas', in Brugué, Q. \& Subirats, J. (eds.) Lecturas de gestión pública, pp 321-352. Madrid: Instituto Nacional de Administración Pública..

Bisquerra, R. ed. (2004) Metodologia de la investigación educativa. Madrid: La Muralla.

Bonet, LL. (2004) 'Reflexiones a propósito de Indicadores y Estadísticas Culturales'. Portal Iberoamericano de Gestión Cultural, Boletín de Gestión Cultural, núm.7: Indicadores y estadísticas culturales. Available at: http://www.gestioncultural.org/boletin/2004/boletinIndicadores.htm. (site visited: 15 mach 2008)

Carrasco, S (1999) Anàlisi Factorial Aplicado a Indicadores Socioculturales de la Comunidad Valenciana. Ph.D. València: Universitat de València. Unpublished manuscript.

Ciudades y Gobiernos Locales Unidos (2006) Indicadores cultures y Agenda 21 for Culture. Document adopted on 24 October 2006 in Barcelona, at the first meeting of the Working Group on Culture of UCLG. Ciudades y Gobiernos Locales Unidos. Available at: http://www.agenda21culture.net. (site visited: 3 february 2008)

Cohen, L. \& Manion, L. (2002) Métodos de investigación educativa. Madrid: La Muralla.

Cobb, C.W \& Rixford, C. (1998) Lessons learned from the history of social indicators. San Francisco: Redefining Progress.

De la Durantaye (2002) 'Municipal Cultural Policies in Quebec', Canadian Journal of Communication, 27, pp 305-313

Duxbury, N. (2007) Cities and Communities: Cultural Indicators at the Local Level. Workshop report. Centre of Expertise on Culture and Communities, Creative City Network of Canada. Available at: http://www.cultureandcommunities.ca/downloads/indicators-2006/ReportIndicators.pdf. (site visited: 15 april 2008)

Federación Española de Municipios y Províncias (2007) Sistema de indicadores para la evaluación de las políticas culturales locales en el marco de la Agenda 21 for Culture. Unpublished manuscript.

Hawkes, J. (2001) The fourth Pilar of Sustainability. Culture's essencial role in public planning. Victoria: Cultural Development Network. 
International Federation of Arts Councils and Culture Agencies (IFACCA), (2005) Statistical Indicators for Arts Policy. Sydney: IFACCA. Available at: http://www.ifacca.org/files/statisticalindicatorsforartspolicy.pdf (site visited: 15 february 2007)

Kingsley, G.T. ed. (1999) Building and operating neighborhood indicator systems: a guidebook. National Neighborhood Indicators Partnership. The Urban Institute. Available at: http://www2.urban.org/nnip/publications.html\#operating. (site visited: 20 february 2007)

Landry, L. Greene, L.; Matarasso, F. \& Bianchini, F. (1996) The Art of Regeneration: Urban renewal through cultural activity. Stroud: Comedia.

Landry, L. \& Bianchini, F. (1994) The Creative City. Working Paper 3: Indicators of a Creative City. Stroud: Comedia.

López de Aguileta, I (2000) Cultura y ciudad. Manual de política cultural municipal. Gijón: Trea.

Matarasso, F. (1999) Towards a Local Culture Index: measuring the cultural vitality of communities. Nottingham: Comedia

Museums, libraries and archives council (2005) Developing performance indicadors for local authoriy museums, libraries and archives. London: Victoria House.

Planas, A. (2009) L'avaluació de polítiques socioculturals municipals: una proposta d'indicadors. Ph.D. Girona: University of Girona. Unpublished manuscript.

Poirier (2005) 'Vers des indicateurs culturels élargis? Justificatifs des politiques culturelles et indicateurs de performance au Québec et en France' in Andrew, C. Et al. ed. (2005) Accounting for Culture: Thinking Through Cultural Citizenship, pp235-256. Ottawa: University of Ottawa Press.

Pose, H.M. (2006) La cultura en las ciudades. Un quehacer cívico-social. Barcelona: Graó.

Robinson, J ed. (2005) Eurocult21. Integrated Report. Helsinki: Eurocult 21. Available at: http://www.eurocult21.org/ (site visited: 10 january 2007)

Rodríguez, G; Gil, J. \& Garcia, E. (1996) Metodología de la investigación cualitativa. Màlaga: Ediciones Aljibe.

Stake, R.E (1998) Investigación con estudio de casos. Madrid: Ediciones Morata.

Vázquez, R \& Angulo, F ed. (2003) Introducción a los estudios de caso; los primeros contactos con la investigación etnogràfica. Màlaga: Ediciones Aljibe.

Viñas, V (2009) 'The European Union's Drive towards Public Policy Evaluation: The Case of Spain', Evaluation, 15(4): pp459-472

Walesh, K. \& Henton, D. (2001) The creative community. Leveraging Creativity and Cultural Participation for Silicon Valley's Economic and Civic Future. Cultural Initiatives Silicon Valley. Available at: http://www.ci-sv.org/cna_creative.shtml. (site visited: 15 july 2007) 